\title{
Financial Expense Incurred by Medical Leaves of Health Professionals in Rondonia Public Hospitals, Brazil
}

\author{
Maria Bernadete Junkes ${ }^{1}$ \\ Valdir Filgueiras Pessoa ${ }^{2}$
}

\begin{abstract}
The study investigates the additional payroll expense caused by absenteeism due to illness among nursing professionals and physicians at two public hospitals at Cacoal, Rondonia, Brazil. Non-programmed absences of up to 15 days which occurred at the hospital units between 2004 to 2007 were verified in the database of the institutions' human resource sector. From 1,704 non-programmed absences, 1,486 were justified by medical declarations. It was verified that absenteeism caused by illness was responsible for $87.2 \%$ of all nonprogrammed absences. When these data are grouped by professional categories, it was observed that the nurse absenteeism due to illness reached $83.3 \%$, when compared with $16.7 \%$ for physicians. The general absenteeism index, adding up nurses and physicians, corresponded to $0.85 \%$, resulting in an additional payroll expense of $5.2 \%$ and $7.4 \%$ in the salaries of nursing professionals and physicians, respectively.

Descriptors: Absenteeism; Hospitals, Public; Nurses, Male; Physicians.
\end{abstract}

\footnotetext{
${ }^{1}$ Doctoral Student in Nursing Sciences, Faculdade de Ciências da Saúde, Universidade de Brasilia, DF, Brazil. Faculty, Fundação Universidade Federal de Rondônia, AC, Brazil. E-mail: mbjunkes@yahoo.com.br.

2 Physician, Postdoctoral in Neurophysiology, Adjunct Professor, Universidade de Brasília, DF, Brazil. E-mail: vpessoa@unb.br.
}

Corresponding Author:

Maria Bernadete Junkes

Fundação Universidade Federal de Rondônia. Campus Cacoal

Rua da Universidade, 920. Brizon

CEP: 78975-155 Cacoal, RO, Brasil

E-mail: bernadetejunkes@unir.br e bernadetejunkes@gmail.com 


\title{
Gasto financeiro ocasionado pelos atestados médicos de profissionais da saúde em hospitais públicos no Estado de Rondônia, Brasil
}

O objetivo deste estudo foi investigar o gasto adicional na folha de pagamento, causado pelo absenteísmo doença de profissionais de enfermagem e médicos, em dois hospitais públicos da cidade de Cacoal, Rondônia, Brasil. Foram verificadas ausências não programadas de até 15 dias nas unidades hospitalares, no período de 2004 a 2007, observadas no banco de dados do setor de recursos humanos das instituições. Constatou-se 1.704 ausências não programadas, das quais 1.486 são justificadas por atestados médicos. Verificou-se que o absenteísmo por motivo de doença foi responsável por $87,2 \%$ das ausências não programadas. Se for descrito por categoria de profissional, o absenteísmo doença dos profissionais de enfermagem atingiu índice de 83,3\% e dos médicos $16,7 \%$. O índice do absenteísmo geral dos profissionais de enfermagem e médicos foi de $0,85 \%$, enquanto que o gasto adicional na folha de pagamento no período atingiu 5,2\% nos vencimentos dos profissionais de enfermagem e 7,4\% dos médicos.

Descritores: Absenteísmo; Hospitais Públicos; Enfermeiros; Médicos.

\section{El gasto financiero causado por las licencias médicas de profesionales de la salud en los hospitales públicos en Rondonia, Brasil}

\begin{abstract}
El objetivo de este estudio fue investigar el gasto adicional en la planilla de pago, causado por el absentismo enfermedad de profesionales de enfermería y médicos, en dos hospitales públicos de la ciudad de Cacoal, en Rondonia, Brasil. Fueron verificadas ausencias no programadas de hasta 15 días en las unidades hospitalarias, en el período de 2004 a 2007, constatadas en el banco de datos del sector de recursos humanos de las instituciones. Se constató 1.704 ausencias no programadas, de las cuales 1.486 son justificadas con certificados médicos. Se verificó que el absentismo por motivo de enfermedad fue responsable por $87,2 \%$ de las ausencias no programadas. Si fuese descrito por categoría profesional, el absentismo enfermedad de los profesionales de enfermería alcanzaría el índice de $83,3 \%$ y el de los médicos 16,7\%. El índice de absentismo general de los profesionales de enfermería y médicos fue de $0,85 \%$, en cuanto que el gasto adicional en la planilla de pago en el período alcanzó 5,2\% en los salarios de los profesionales de enfermería y $7,4 \%$ de los médicos.
\end{abstract}

Descriptores: Absentismo; Hospitales Públicos; Enfermeros; Médicos.

\section{Introduction}

The causes of absenteeism in hospitals, such as diseases, non-programmed or unjustified absences, locomotion problems, family motives, demotivation, inadequate policies, precarious supervision by managers and occupational accidents, among others, may indicate that professionals reject the job, due to the fact that, in most cases, these absences are short. Factors like insufficient staff though, in combination with lack of medication and equipment, demonstrate that public hospitals face economic and financial difficulties ${ }^{(1)}$.
In the financial situation, spending control is a fundamental work instrument to optimize hospital operations. Cost is considered as spending related to goods or services used to produce other goods and services. Hence, any payment to health professionals working in hospitals is classified as workforce spending(2).

Absenteeism is the absence from work due to programmed (holidays, maternity leave, congress leave and others) and non-programmed motives (health leave, unjustified absences, suspension) and represents 
a crucial problem for public organizations and their managers. It causes not only direct but also indirect costs, due to decreased productivity, care quality and administrative problems ${ }^{(3)}$.

In a country like Brazil, whose salary standard does not permit losses, some causes of absenteeism are disguised as absenteeism due to disease. This stimulates indiscriminate forms of justifying these absences by means of medical declarations. Spending on absenteeism due to disease is higher than the salary paid to the ill worker, who does not attend the workplace, affecting productivity $^{(3)}$.

In this context, Cacoal, a city in the Central-South of Rondônia, a Brazilian state, with an approximate population of 78 thousand inhabitants, offers six hospitals, two of which are public and attend to the largest part of service demands. The city also faces problems to deal with its health professionals. Management normally does not question absenteeism at these public hospitals, resulting from non-programmed absences, particularly short ones, and justified by medical declarations of up to 15 days, with significant frequencies.

It should be reminded that public hospitals are funded by the actions and services performed, as they need to present productivity reports, showing what procedures were carried out. Therefore, registration and control mechanisms need to be adopted, based on worksheets provided by the Ministry of Health. Thus, workers' absence can mean decreased productivity and fewer resources to be applied.

Hospitals in general are far from being model organizations, as they expose their workers to situations marked by work overload, chronic and lethal diseases, infrastructural deficiencies, repetitive strain injuries and work related musculoskeletal disorders (RSI/ WRMD $^{(4)}$, thus contributing to the strengthening of nonprogrammed absences. Several studies have confirmed these facts, as follows.

In the United Kingdom, in 2005 for example, at an eye hospital, $26 \%$ of postoperative problems were due to nursing professionals' absenteeism, who justified their absences by low remuneration levels(5).

At two asylum institutions in the USA in 2003 and 2004, health professionals practiced absenteeism due to the salaries they received and the precarious work conditions. In another research in Minnesota, carried out in 1996, absenteeism due to physical injury at the workplace predominated, generating US\$11,417 of public spending per person per year for nurses and US\$ 6,822 for physicians ${ }^{(6-7)}$.

In some states in India, health professionals' absence reached 67\% between 1991 and 2001, due to decreased investments in health. In Venezuela, in 2001, the ratio of absenteeism due to disease registered for resident physicians was around $13 \%$ and for nurses $7 \%$. As a result, in 2003, the World Bank disseminated absenteeism ratios in health in underdeveloped countries like Bangladesh (42\%), Honduras (27\%), India (43\%), Peru (26\%) and Uganda (35\%) $)^{(8-9)}$.

In Brazil, absenteeism research among health professionals is more concentrated in the South and Southeast. To give an example, at Complexo Hospitalar Santa Casa, in 12 months (2003-2004), 68\% of professionals were absent due to health problems or medical appointments, during the following periods: $33.3 \%$ up to nine days, $21.8 \%$ between 10 and 24 days, $10.3 \%$ between 25 and 99 days and 2.6\% declared absences of more than 100 days. At a university hospital in the State of Paraná, among 494 health leaves (between July 1997 and June 1998), absences represented 1,491 days not worked(4,10).

At a hospital in São José do Rio Preto, a city in São Paulo State, $75.4 \%$ of absences from work were due to health problems. At the Hospital das Clínicas in Ribeirão Preto, in 1998, absenteeism due to headache, which $91 \%$ of employees presented, resulted in a $56.9 \%$ productivity loss, and an average of 6.5 days lost per month. The total estimated cost per year was US\$ $815,622.54$, i.e. US\$ 199.42 per employee per year ${ }^{(11-12)}$.

In the North, at a psychiatric center in Manaus, AM, 298 non-programmed absences were registered in 2004-2005, $57.05 \%$ of which were justified by a medical declaration, resulting in 464 days of absence. Hence, the nursing professionals mean absenteeism ratio was $2.9 \%{ }^{(13)}$.

Based on the above data and publications about absenteeism, it was verified that most research results present causal factors of absenteeism among health professionals and the respective absenteeism ratios, however, without any comparison with financial expenses. Therefore, additional discussion is needed about economic/financial ratios in regions about which little research has been done, which can contribute to analyses in new studies that appoint deficiencies in the allocation and distribution of financial resources that are part of municipal public hospitals' budget. 
In view of the above, this research aimed to demonstrate the scenario of implicit payroll expenses caused by non-programmed absences justified by a medical declaration, lasting up to 15 days, without taking into account the description of the nursing professionals and physicians' disease.

This research among nursing professionals and physicians is considered relevant because they are responsible for almost $90 \%$ of productivity in hospital institutions.

\section{Methods}

The research was carried out at two public hospitals in Cacoal, at $485 \mathrm{~km}$ from the state capital Porto Velho, in Rondônia, Brazil, between January and April 2008. Quantitative and qualitative variables were addressed with a retrospective and analytic approach, through an information survey in the database of the institutions' human resource department.

The information collection instrument was adapted ${ }^{(1)}$ and included the following variables: reason for leave, functional category, time of absence, gender and time on the job. In compliance with Resolution 196/96 by the Ministry of Health's National Health Council, approval for the research was obtained from the Research Ethics Committee at Faculdade de Ciências Biomédicas de Cacoal - FACIMED, in March 2007.

The research sample included all nursing professionals and physicians working at these hospitals between 2004 and 2007. Non-programmed absences for up to 15 days were detected in frequency worksheets. The amounts described to support additional payroll expenses correspond to each category's initial baseline salary in 2007, together with the basic gross salary received and distinguishing gratifications and bonuses.

To facilitate result descriptions, hospitals were called $\mathrm{H} 1$ and $\mathrm{H} 2$. $\mathrm{H} 1$ is a hospital unit with 47 active beds and 204 collaborators, with 28 physicians, 7 nurses, 6 nurse technicians and 56 nurse auxiliaries. The hospital delivers care to children and pregnant women, including high-risk patients.

$\mathrm{H} 2$ in turn is a hospital unit with 45 active beds and 228 collaborators, with 38 physicians, 3 nurses, 1 nurse technicians and 33 nurse auxiliaries; it is an urgency and emergency unit that performs medium-complexity procedures.

Frequency worksheet notes supported the calculation of absenteeism ratios due to non-programmed absences and percentages related to additional expenses due to these professionals' replacement on the respective workdays.

Significant variation was observed in contractual salaries, depending on the period the professional was hired in, such as inclusion of overtime, gratifications due to specialization and incentives determined by law. Thus, besides the officially registered basic salary, some advantages and gratifications are added to the paycheck, offering professionals an increased income at the end of the period, which in some cases exceeds $500 \%$. Therefore, the researchers decided to use the initial baseline salary and the total initial salary with additions.

To calculate additional payroll expenses, for nursing professionals, the number of days was multiplied by the hours worked on that day, in this case eight hour, and again multiplied by the overtime payment per hour. Physicians, on the other hand, receive a fixed amount of $\mathrm{R} \$ 700.08$ (seven hundred reais and eight cents) for 24-hour shifts. The human resource departments at the hospitals informed the nursing professionals and physicians' salaries.

The absenteeism ratio was based on the formula below $^{(3)}$ and calculated in Microsoft Office Excel 2007. In this case, the total number of unforeseen days of absence from work is divided by the total number of workdays worked during the period, discounting days related to vacations, holidays and weekends, which adds up to 272 days per year, multiplied by the number of professionals in the category under analysis. This result was multiplied by 100 to achieve the percentage ratio.

$$
\text { Absenteeism ratio }=\frac{\text { Total days of unforeseen absence from work }}{\text { Mean number of employees } * \text { Number of workdays during period }} \times 100
$$

\section{Results}

The survey revealed 1,704 non-programmed absences of nursing professionals and physicians at the two hospitals between 2004 and 2007, 1,486 of which were justified by medical declarations and only 218 were 
left unjustified, that is, simply described as absences. It should be reminded that the number of workdays during the four-year period was 1,088 (one thousand eighty-eight). Multiplied by the number of professionals included in this research, this resulted in 176,256 (one hundred seventy-six thousand two hundred and fiftysix) days, reaching an absenteeism ratio of $0.85 \%$. Specifically with regard to absenteeism with a medical declaration, this was responsible for $87.2 \%$ of all nonprogrammed absences. If described per professional category, the ratio for nursing professionals was $83.3 \%$ and for physicians $16.7 \%$.

Two hundred ninety medical declarations were issued over four years, $63 \%$ for up to three days, $12.8 \%$ up to six days, $6 \%$ up to nine days, only $2 \%$ up to 12 days and the remaining $16.2 \%$ up to 15 days of absence from labor activities. Based on the number of declarations issue, during the four years, there were 1,088 workdays worked, with 904 non-programmed absences at $\mathrm{H} 1$ and 582 at $\mathrm{H} 2$.

Based on the collected information, additional payroll expenses between 2004 and 2007 were simulated, spent on workers at the two study hospitals. It should be highlighted that, when absent workers need to be replaced, only municipal workers can replace them. Thus, for the sake of calculations, the salaries of municipal public servants were considered, as contractually established and specificied in Table 1.

Table 1 - Health Office's additional payroll expense in R\$ to cover unprogrammed absence between 2004 and 2007

\begin{tabular}{|c|c|c|c|c|c|c|c|}
\hline Contract & Function & Initial salary & $\begin{array}{c}\text { No. of days } \\
\text { absent }\end{array}$ & Cost of overtime & $\begin{array}{l}\text { Overtime during } \\
\quad 4 \text { years }\end{array}$ & $\begin{array}{c}\text { Additional } \\
\text { payroll expense }\end{array}$ & Additional ratio \\
\hline \multirow[t]{3}{*}{ Federal } & Physician & $1,342.32$ & 30 & & & & \\
\hline & Nurse & * & - & - & - & - & - \\
\hline & Nurse Aux. & 402.62 & 509 & - & - & - & - \\
\hline \multirow[t]{3}{*}{ State } & Physicians & $1,566.00$ & 22 & - & - & - & - \\
\hline & Nurse & 903.54 & - & - & - & - & - \\
\hline & Nurse Aux. & 450.45 & 174 & - & - & - & - \\
\hline \multirow[t]{4}{*}{ Municipal } & Physician & 908.17 & 196 & $700.08 / 24 h$ & $173,620.00$ & $179,554.00$ & $7.4 \%$ \\
\hline & Nurse & 875.10 & - & $6.57 / \mathrm{h}$ & - & - & - \\
\hline & Nurse Tech. & 528.00 & 18 & $3.96 / \mathrm{h}$ & 570.00 & 865.00 & $0.5 \%$ \\
\hline & Nurse Aux. & 465.00 & 537 & $3.50 / \mathrm{h}$ & $34,160.00$ & $40,783.00$ & $5.2 \%$ \\
\hline
\end{tabular}

Source: Human Resources Dept. at H1 and H2 - adapted by the authors (2008).

The amounts paid during four years result from adding up the professionals' absences, multiplied by the cost of overtime. In the case of physicians, for example, all days of absence were added up and multiplied by one single value, due to the fact that the category receives per shift $(30+22+196=248 * 700.08=R \$ 173,620.00)$. Next, the normal salary they were entitled to was added up, resulting in $179,554.00$ (one hundred seventy-nine thousand five hundred fifty-four reais). As for other nursing professionals, days of absence were added up and multiplied by eight hours, due to the fact that salaries are determined in hours instead of days, like for physicians (e.g. Nurse Aux. $=509+174+537=1,220 * 8=9,760 * \mathrm{R} \$ 3.50=\mathrm{R} \$$ $34,160.00)$. To reach the additional payroll expense, the normal amount that was not discounted during the period of justified absences was added up.

The additional expense ratio was found based on the remuneration by the municipal professionals' initial baseline salary during the study period, as demonstrated in Table 2. Table 2 also presents the amount of salaries that is not paid to cover for absenteeism justified by medical declarations, showing both the initial baseline salary for the category and the average salary received in each category, in 2007. With regard to physicians, the ratio was $7.4 \%$ higher than the category's entire remuneration, that is, 198 baseline salaries were not paid, equivalent to 34 salaries with gratifications and bonuses. Second are nurse auxiliaries, with a $5.2 \%$ additional payroll expense, resulting in 88 baseline salaries or 34 salaries with gratifications and bonuses. 
Table 2 - Salaries paid to cover absenteeism due to disease between 2004 and 2007

\begin{tabular}{|c|c|c|c|c|c|c|c|}
\hline Contract & Function & Initial salary & Total salary & $\begin{array}{l}\text { Baseline salary } \\
\text { paid in } 4 \text { years }\end{array}$ & $\begin{array}{l}\text { Additional due } \\
\text { to absences }\end{array}$ & $\begin{array}{c}\text { Equivalent baseline } \\
\text { salary in } 4 \text { years }\end{array}$ & $\begin{array}{l}\text { Equivalent total } \\
\text { salary in } 4 \text { years }\end{array}$ \\
\hline \multirow[t]{3}{*}{ Federal } & Physician & $1,342.32$ & $9,092.72$ & - & - & - & - \\
\hline & Nurse & * & * & - & - & - & - \\
\hline & Nurse Aux. & 402.62 & $3,108.67$ & - & - & - & - \\
\hline \multirow[t]{3}{*}{ State } & Physicians & $1,566.00$ & $6,168.00$ & - & - & - & - \\
\hline & Nurse & 903.54 & $3,887.57$ & - & - & - & - \\
\hline & Nurse Aux. & 450.45 & $1,188.48$ & - & - & - & - \\
\hline \multirow[t]{4}{*}{ Municipal } & Physician & 908.17 & $5,347.67$ & $2,441,161.00$ & $179,554.00$ & 198 & 34 \\
\hline & Nurse & 875.10 & $1,254.60$ & - & - & - & - \\
\hline & Nurse Tech. & 528.00 & $1,167.90$ & $165,564.00$ & 865.00 & 1.6 & 0.75 \\
\hline & Nurse Aux. & 465.00 & $1,198.42$ & $782,602.00$ & $40,783.00$ & 88 & 34 \\
\hline
\end{tabular}

Source: Human Resources Dept. at H1 and H2 - adapted by the authors (2008).

Despite the limitations of the notes made in nursing professionals and physicians' files, some medical declarations showed the occupational illnesses that led to these absences, through the identification of the ICD - International Classification of Diseases. These data indicate that $48 \%$ of absenteeism caused by disease was related to musculoskeletal disorders, known as RSI/ WRMD. Moreover, $12 \%$ presented mild inflammation (tonsilitis) and 15\% depression, with absences of more than 10 days. Dengue fever was responsible for $5 \%$ of absences and headache for the remaining $20 \%$.

At the two hospitals, no predominance of absenteeism after holidays was found, but at weekends, when professionals were supposed to be on duty. In addition, some professionals bring on frequent notes during the study periods, that is, absences were registered in most months.

Data analysis showed that the average productivity at the two hospitals in Cacoal was 300 thousand procedures during the study period. More specifically in 2007, considering the resident population, this meant a cost per inhabitant of $\mathrm{R} \$ 214.33$ (two hundred fourteen reais and thirty-three cents). Among the factors involved in these results, the collaborators stand out, as these contributed to the generation of these expenses during the research period, corresponding to $61 \%$.

\section{Discussion}

The ratios found in this research are high when compared with other countries in South America, like Venezuela with $13 \%$ for resident physicians and $7 \%$ for nurses ${ }^{(9)}$, or even with India $(67 \%$ for health professionals)(8), where investments in the health area decreased between 1991 and 2001. However, absenteeism ratios at the study hospitals in Cacoal are comparable to ratios reported in some hospitals in the South and Southeast: $79.2 \%$ in Porto Alegre ${ }^{(4)}$, $75.4 \%$ in São José do Rio Preto(11). Medical declaration percentages are also high when compared with surveys at the Complexo Hospitalar Santa Casa in Porto Alegre in 2003-2004(10), and in Manaus, corresponding to $2.9 \%{ }^{(13)}$

Although the cause of non-programmed absences was not a fundamental goal in this research, data related to the origins of absenteeism are in line with research performed at the University Hospital in São Paulo State in 2000 where, out of 1988 medical declarations issued, $84.2 \%$ was related to diseases of the digestive system. At the Teaching Hospital in Uberaba, MG, in 2002, medical declarations indicated $21.57 \%$ of back pain, $13.73 \%$ of headache, $8.82 \%$ of rhinitis and respiratory problems, $5.9 \%$ of hypertension and limb pain and the remainder occupational accidents due to biological hazards ${ }^{(14-15)}$.

While the ratio of absenteeism due to disease was $0.85 \%$, when considered in days not worked, additional payroll expenses varied considerably. The ratio corresponded to $5.2 \%$ for nurse auxiliaries, which is six times higher when related with the absenteeism ratio. The ratio for medical professionals corresponded to expenses 8.5 times higher.

This difference between the ratio of absenteeism due to disease and the ratio of additional payroll expenses is not evidenced in most cases. Another fact that stands out is that the most severe absenteeism due to disease is concentrated in professionals with more than five years at the research institutions, perhaps because they are keeping the stability of their job in mind. This observation is based on informal conversations with the researchers and perceived in some frequency worksheets, which even show some professionals with more than two years of absence due to illness. 
Absenteeism could be minimized at the municipal hospitals by putting in practice and adapting policies that allow for a better work environment, bonus practices by managers, cultures that privilege participation, as well as interventions in occupational health promotion and in adequate health staff dimensioning, in line with strategies previously suggested in research in the North of Brazil(13).

One example of changes in job policies comes from the Hollywood Confidential Hospital in Western Australia, which reduced absenteeism ratios to $2.24 \%$ by using the EEO - Equal Employment Opportunity - a federal law that established the family-friendly program, in which patients' relatives help hospital workers ${ }^{(16)}$.

\section{Final considerations}

The research revealed the payroll expenses caused by non-programmed absences and absences justified by medical declarations, for periods of up to 15 days, without leading to remuneration losses. The results can also contribute to statistics about the expenses absenteeism generates at hospital institutions in Brazil, which have stood out in the last two decades, and join extremely important data to support managers in strategic planning, with a view to setting up policies needed for adequate financial resource allocation in the health area.

Based on the premise that it is through hard and responsible work that institutional results are achieved, which in this case means attending to the population's health needs, absenteeism is essentially understood as a management problem. In a recent study about absence from nursing work, the authors argue that data obtained in that type of research can support interventions to improve current work conditions, decreasing economic and social costs in this context. The authors also hope that the present research can somehow contribute for hospital managers in Cacoal to turn the demonstrated expenses into strategies that motivate their collaborators, such as a career plan, reduced spending on medication and assiduity awards, among others.

\section{References}

1. Murofuse NT. O adoecimento dos trabalhadores de enfermagem da Fundação Hospitalar do Estado de Minas Gerais: reflexo das mudanças no mundo do trabalho. [tese]. Ribeirão Preto (SP): Escola de Enfermagem de Ribeirão Preto/Universidade de São Paulo; 2004. [acesso em: 02 mar. 2007]. Disponível em www. teses.usp.br/teses

2. Martins E. Contabilidade de custos. 9a ed. São Paulo (SP): Atlas; 2006.

3. Chiavenato I. Gestão de Pessoas. Edição compacta. $2^{a}$ ed. São Paulo (SP): Atlas; 2004.

4. Silva DPP, Marziale MHP. Problemas de saúde responsáveis pelo absenteísmo de trabalhadores de enfermagem de um hospital universitário. Rev Latino-am Enfermagem. 2000; 8(5):44-51.

5. Baylis OJ, Adams WE, Allen D, Fraser SG. Do variations in the theatre team have an impact on the incidence of complications? [serial online] 2006. BMC Ophthalmol. 2006. 6:13. [Acesso em: 13 ago. 2006]. Disponível em: http://www. pubmedcentral.nih.gov/

6. Mc Govern P, Kochevar L, Lohman W, Zaidman B, Gerberich SG, Nyman J, et al. The Cost of Work Related Physical Assaults in Minnesota. HSR: Health Serv Res. 2000; 35(3):663-86.

7. Castle N, Degenholtz H, Rosen J. Determinants of staff job satisfaction of caregivers in two nursing homes in Pennsylvania. BMC Health Serv Res 2006; 60(6):1-11.

8. Varatharajan D. Provision of Health Care by the Government. Indian J Med Ethics. [acesso em: 16 nov 2006]. Disponível em: http://www.issuesinmedicalethics.org/

Received: May. $1^{\text {st }} 2009$

Accepted: Dec. $20^{\text {th }} 2009$
9. Garcia-Prado A, Chawla M. The impact of hospital management reforms on absenteeism in Costa Rica. Healthy Police Plan. [serial online]. 2006. 21(2):91-100. [Cited 2008 nov 16]. Disponível em: http://heapol.oxfordjournals.org/cgi/content/ abstract/21/2/91

10. Raffone AM, Hennington EA. Avaliação da capacidade funcional dos trabalhadores de enfermagem. Rev Saúde Pública. 2005; 39(4):669-76.

11. Barboza DB, Soler ZASG. Afastamento do trabalho na enfermagem: ocorrência com trabalhadores de um hospital de ensino. Rev. Latino-Am. Enfermagem. 2003; 11(2):177-83.

12. Bigal ME, Moraes FA, Fernandes LC, Bordini CA, Speciali JG. Indirect Cost of Migraine in a Public Brazilian Hospital. Headache. 2001; 41(5):503-8.

13. Becker SG, Oliveira MLC. Estudo do absenteísmo dos profissionais de enfermagem de um centro psiquiátrico em Manaus, Brasil. Rev. Latino-Am. Enfermagem. 2008; 16(1):109-14.

14. Reis JR, La Rocca PF, Silveira AM, Bonilla IML, Giné NA, Martín M. Fatores relacionados ao Absenteísmo por doença em profissionais de enfermagem. Rev Saúde Pública 2003; 37(5):616-23.

15. Rezende MP. Agravos à saúde de auxiliares de enfermagem resultantes da exposição ocupacional aos riscos físicos [dissertação]. Ribeirão Preto (SP): Escola de Enfermagem de Ribeirão Preto, Universidade de São Paulo; 2003. [acesso em: 10 jul 2007]. Disponível em www.teses.usp.br/teses 16. Cass-Ryall K. Hollywood Private Hospital. [acesso em: 13 ago 2006]. Disponível em: http://www.eowa.gov.au/ 